Khazanah: Jurnal Studi Islam dan Humaniora

ISSN: 0215-837X (p); 2460-7606 (e), Vol. 16 (2), 2018, pp. 203-226

DOI: $\underline{10.18592 / \text { khazanah.v16i2.2336 }}$

\title{
FENOMENA JILBAB DALAM MASYARAKAT KOSMOPOLITAN: INTERPRETASI TEKS DAN KONTEKS ATAS AYAT JILBAB
}

\author{
Yulia Hafizah \\ Universitas Islam Negeri Antasari Banjarmasin \\ yuliahafizah@,uin-antasari.ac.id
}

\begin{abstract}
This paper aims to reveal the various interpretations of ulama to the text of veil and it's relevance to the current development context. This paper is the result of literature research (library research) which is arranged in the form of papers. Data mining is carried out by exploring various sources that are relevant to this research, namely reviews from the mufassir, both classical and contemporary related to the veil verse in Alqur'an, namely Q.S. al-A $\underline{\text { hzâb: }} 59$ and an-Nûr: 31, then compiled and read with a historically critical approach. This paper shows that the various ideas of classical and contemporary ulama are inseparable from the social context of their time. This social context ultimately makes the veil no longer just a symbol of identity, but more than that. The appearance of various hijab communities which later formed a new social movement has brought modern value in lifestyle and opened opportunities for the development of new sectors in the economy.
\end{abstract}

Keywords: Veil, Cosmopolitan Society, Text, Context

\begin{abstract}
Abstrak: Paper ini bertujuan untuk mengungkapkan berbagai interpretasi ulama terbadap teks jilbab dan relevansiny a dengan konteks perkembangan saat ini. Tulisan ini merupakan hasil penelitian literatur (library research) yang disusun dalam bentuk makalab (paper). Penggalian data dilakukan dengan melakukan eksplorasi terbadap berbagai sumber yang relevan dengan penelitian ini, yakni ulasan dari para mufassir, baik klasik ataupun kontemporer terkait dengan ayat jilbab dalam Alqur'an, yakni Q.S. al-Abzzâb: 59 dan anNûr: 31, yang kemudian disusun dan selanjutnya dibaca dengan pendekatan bistoris kritis. Paper ini menghasilkan bahwasanya beragam pemikiran ulama klasik dan kontemporer tidak terlepas dari konteks sosial dimasa mereka berada. Konteks sosial ini pada akbirmya menjadikan jilbab itu bukan lagi hanya merupakan sebuah simbol identitas, tetapi lebih dari itu. Tampilnya beragam komunitas jilbab yang kemudian membentuk sebuah gerakan sosial baru telah membawa nilai modern dalam gaya hidup serta membuka peluang bagi berkembangnya sek.tor baru dalam perekonomian.
\end{abstract}

Kata kunci: Jilbab, Masyarakat Kosmopolitan, Tekes, Konteks 


\section{Pendahuluan}

Setiap peralihan tahun baru hijriyah, umat Islam di banyak tempat senantiasa meramaikan dengan refleksi arti penting tahun baru Islam tersebut. Saat ini, tahun baru hijriyah yang diawali pada bulan Muharram telah berusia 1440 tahun, yang apabila dihitung menggunakan skala ukuran ratusan (abad) telah berusia 15 abad, atau lebih tepatnya sudah 40 tahun posisi kita berada di dalam abad ke-15 Hijriyah.

Hadirnya abad ke-15 hijriyah dipenghujung tahun 1970-an, menjadi momentum kegembiraan bagi banyak umat Islam. Mitologi siklus 7 abad umur sebuah peradaban, diyakini sebagai sebuah pertanda kebangkitan setelah keterpurukan selama 7 abad sebelumnya. Kebangkitan Islam (Islamic resurgencel an Nabdhah al Islâmiyyah), merupakan suatu gerakan yang mengacu pada: pandangan dari kaum Muslim sendiri bahwa Islam menjadi penting kembali; Islam dikaitkan dengan masa lalunya yang gemilang hingga masa lalu tersebut memengaruhi pemikiran kaum Muslim sekarang; Islam dipandang sebagai alternatif, dan karena itu dianggap ancaman bagi pandangan hidup atau ideologi lain yang sudah mapan, khususnya ideologi-ideologi Barat. ${ }^{1}$

Menurut John L. Esposito, meski ada banyak varian penjelasan terkait kebangkitan Islam, setidaknya bisa disederhanakan menjadi tiga hal: Pertama, krisis identitas umat Islam yang diakibatkan ketidakberdayaan, kekecewaan dan kehilangan harga diri; kedua, kekecewaan terhadap Barat dan kegagalan pemerintah untuk bereaksi terhadap kebutuhan politik, sosial dan ekonomi masyarakat; ketiga, tumbuhnya rasa harga diri dan kesadaran akan kekuatan sendiri akibat sukses militer (Arab-Israel) dan faktor ekonomi (embargo minyak) tahun $1973 .{ }^{2}$

${ }^{1}$ Chandra Muzaffar, "Kebangkitan Islam: Suatu Pandangan Global Dengan Ilustrasi Dari Asia Tenggara," in Pembangunan Dan Kebangkitan Islam Di Asia Tenggara, ed. Saiful Muzani (Jakarta: LP3ES, 1993), 58.; Ibrahim M. Abu-Rabi', Intellectual Origins of Islamic Resurgence in the Modern Arab World (New York: SUNY Press, 1996).

${ }^{2} J o h n$ L Esposito and Bakri Siregar, Dinamika Kebangunan Islam: Watak, Proses dan Tantangan (Jakarta: Rajawali, 1987), 14. 
Revolusi Islam Iran pada tahun 1979 yang dipimpin oleh Khomeini juga semakin menambah semangat kebangkitan Islam. ${ }^{3}$ Revolusi Iran menurut Burrell memiliki makna penting yang menunjukkan bahwa kekuatan Islam mampu menggulingkan suatu rezim yang pro Barat dan sangat kuat pada masa itu. ${ }^{4}$ Semangat pemerintahan Khomeini ${ }^{5}$ untuk 'menularkan' revolusinya ke berbagai kawasan Islam lainnya, turut memberikan ghirah baru untuk kembali kepada Islam dan bangga beragama Islam, dan salah satu bentuk nyata yang bisa dilihat dari fenomena kebangkitan Islam ini, ada pada perubahan cara berbusana perempuan di berbagai dunia Islam, tidak terkecuali di Indonesia.

Revolusi Iran telah memberikan ruang yang cukup luas bagi perempuan disana untuk berekspresi dengan tetap mengedepankan nuansa keislaman dalam kehidupan mereka. Sebagai contoh pasca revolusi, perempuan disana bebas untuk keluar rumah, berdandan dengan sangat menarik, menggunakan make-up yang cukup menyolok, tetapi tetap harus menggunakan jilbab sebagai penutup kepalanya. Bahkan untuk turis asing pun diharuskan oleh negara untuk menutup tubuh dan kepala mereka dengan menggunakan abaya dan jilbab. Busana wanita tetap menjadi isu yang hangat saat itu. ${ }^{6}$

Semangat kembali kepada Islam yang dimanifestasikan pada tata cara berbusana ini juga berpengaruh terhadap pergerakan kebangkitan di tanah air. Bermula dari aktivitas jamaah Masjid Salman (kampus ITB) dan aktivis Jamaah Shalahuddin (kampus UGM) yang sering mengadakan diskusi-diskusi keagamaan, pada akhirnya turut melahirkan kesadaran baru bagi mahasiswi untuk menutup rambutnya dengan jilbab sebagai

${ }^{3}$ M. Zainal Abidin, "Revolusi Iran \& Kebangkitan Kembali Dunia Islam," in Tafsir Filsafat Atas Kehidupan: Risalah Seputar Filsafat Dan Isu-Isu Aktual Keislaman (Yogyakarta: PP UII Press, 2007), 151-62. $44-45$.

${ }^{4}$ R.M. Burrell, Fundamentalisme Islam, (Yogyakarta: Pustaka Pelajar, 1995), Books, 1984).

${ }^{5}$ Shaul Bakhash, the Reign of the Ayatollahs: Iran and the Islamic Revolution (Basic

${ }^{6}$ M. Fajar Hidayanto, "Aurat Wanita Dalam Aturan Hukum," Al-Mawarid 5 (2016): 82 . 
bagian dari upaya untuk menutup aurat dan sekaligus menunjukkan identitas keislamannya. ${ }^{7}$

Berbagai fenomena back to Islam (kembali kepada Islam) dalam bentuk penggunaan jilbab oleh sebagian kecil perempuan muda muslimah masa itu secara bagus dipotret oleh penyair Taufik Ismail dalam bentuk puisi berjudul 'Aisyah Adinda Kita', yang kemudian dinyanyikan dengan sangat syahdu oleh kelompok BIMBO sekitar tahun 80-an. ${ }^{8}$ Wahyudi Nasution menuliskan terkait fenomena lagu ini: "Sungguh sesuatu yang aneh masa itu, lahirnya lagu tersebut mampu mendorong makin maraknya pemakaian jilbab di kampus-kampus, kantor, sekolah dan tempat umum lainnya."9

Meski pada awalnya pemakaian jilbab diberbagai sekolah dan instansi pemerintahan tersebut sempat mendapat larangan dari pemerintah Orde Baru saat itu yang masih Islamo phobia. ${ }^{10}$ Namun seiring dengan perubahan peta politik pemerintah Orde Baru yang lebih akomodatif terhadap umat Islam-sekitar tahun 1990-an-akhirnya secara resmi pemerintah kemudian mengeluarkan SK No. 100 yang pada intinya berisikan tentang kebolehan memakai jilbab di setiap lembaga pendidikan maupun pemerintahan. ${ }^{11}$

Sejak saat itu, kebebasan pemakaian jilbab ini seakan tidak bisa dibendung lagi. ${ }^{12}$ Perkembangan trend dan model jilbab ini pada akhirnya menampilkan setidaknya terdapat dua kelompok dalam pemakaian jilbab ini. Pertama, mewakili mereka yang ingin kembali ke ajaran Islam

${ }^{7}$ Wahyudi Nasution, "Lautan Jilbab, Episode Awal Menuju Maiyah," MEPNEWS.ID, November 21, 2016, https://mepnews.id/2016/11/21/lautan-jilbabepisode-awal-menuju-maiyah/.

${ }^{8}$ Untuk menikmati dan menghayati isi lagu ini bisa dilihat pada: "Aisyah Adinda Kita Lirik - YouTube," accessed October 13, 2018, https://www.youtube.com/results?search_query=aisyah+adinda+kita+lirik.

"Wahyudi Nasution, "Lautan Jilbab, Episode Awal Menuju Maiyah."

${ }^{10}$ Ainun Najib, "Pementasan Drama Lautan Jilbab Karya Emha Ainun Nadjib Dalam Fenomena Pelarangan Menggunakan Jilbab Bagi Pelajar Muslimah Di SekolahSekolah Negeri Di Indonesia (1986-1989 M)" (PhD Thesis, UIN Sunan Ampel Surabaya, 2017).; Alwi Alatas and Fifrida Desliyanti, Revolusi Jilbab: Kasus Pelarangan Jilbab Di SMA Negeri Se-Jabotabek, 1982-1991 (Al-I'tishom Cahaya Umat, 2001).

${ }^{11}$ Dadi Ahmadi dan Nova Yohana, "Konstruksi Jilbab Sebagai Simbol Keislaman," MediaTor (Jurnal Komunikasi) 8, no. 2 (2007): 235.

${ }^{12}$ Atik Catur Budiati, "Jilbab: Gaya Hidup Baru Kaum Hawa," Jurnal Sosiologi Islam 1, no. 1 (2011). 
sesungguhnya. Kelompok ini mengidentikkan dengan simbol kesalehan, kesopanan dan konservatif, dapat dikenali melalui bentuk jilbab yang besar dan khas, menutup hampir semua tubuh, menggunakan longdress panjang dan longgar. Kedua, sebaliknya, anti thesis dari kelompok pertama. Mereka mewakili simbol kebebasan dan modernitas dengan cara berpakaian menggunakan jilbab kecil dengan warna-warni yang menarik perhatian, diikat atau dililit di leher, baju dan celana ketat. Sebagai seorang muslimah mereka juga tidak mau menanggalkan identitas mereka, namun disisi yang lain mereka juga tidak mau dikatakan sebagai kampungan, tidak trendi atau kuno. ${ }^{13}$

Terbentuknya dua penampilan yang berbeda dari kelompok di atas tentu sangat dipengaruhi oleh faktor budaya dan pemahaman mereka tentang makna dari jilbab itu sendiri. Tulisan ini bermaksud untuk mengulas berbagai interpretasi ulama terhadap pemaknaan teks jilbab itu kemudian membawanya kepada kondisi saat ini, dimana jilbab tidak hanya dipahami sebagai bentuk ketaatan dalam menjalankan perintah agama, juga merupakan hasil dari perkembangan budaya dari masyarakat kosmopolitan.

Secara metode, tulisan ini merupakan hasil penelitian literatur (library research) yang disusun dalam bentuk artikel jurnal. Penggalian data dilakukan dengan melakukan eksplorasi terhadap berbagai sumber yang relevan dengan penelitian ini, yakni ulasan dari para mufassir, baik klasik ataupun kontemporer terkait dengan ayat jilbab dalam Alqur'an, yakni Q.S. al-Ahzzâb: 59 dan an-Nûr: 31, yang kemudian disusun dan selanjutnya dibaca dengan pendekatan historis kritis. Pendekatan ini digunakan untuk mengamati dan menelusuri proses terjadinya sebuah gagasan dan pemikiran berdasarkan konteks sosio-kultural tokoh.

\section{Metode Pembahasan}

\section{Konseptualisasi Jilbab: Interpretasi atas Teks (Nash) Jilbab}

Secara etimologi, jilbab (Indonesia) adalah sebuah kata benda, yang diartikan dengan kerudung lebar yang dipakai wanita muslim untuk

${ }^{13}$ Ahmadi and Yohana, "Konstruksi Jilbab Sebagai Simbol Keislaman,” 236. 
menutupi kepala dan leher sampai dada. ${ }^{14}$ Di Eropa (Barat), istilah jilbab disebut veil atau hijab, digunakan untuk merujuk pada penutup kepala tradisional, wajah (meliputi mata, hidung dan mulut) atau seluruh tubuh perempuan Timur Tengah dan Asia Selatan. Karena makna leksikal dari kata ini mengandung arti menutupi; menyembunyikan atau menyamarkan. Lebih luas lagi kata tersebut digunakan untuk mengungkapkan pada empat hal yakni: (1) kain panjang yang digunakan seorang perempuan untuk menutup kepala, bahunya dan kadang-kadang juga muka; (2) rajutan panjang yang dilekatkan di topi atau tutup kepala perempuan, yang maksudkan untuk mempercantik atau melindungi kepala dan wajah; (3) bagian tutup kepala biarawati yang menjutai ke bawah menutupi bahu; (4) sehelai kain tipis yang digantung untuk memisahkan sesuatu disebaliknya (seperti gorden). ${ }^{15}$

Seperti yang dituliskan Fadma El Guindi dengan mengutip The Encyclopedia of Islam serta hasil penelitian dari Fernea, terdapat ratusan istilah bahasa Arab yang merujuk kepada perangkat pakaian perempuan tersebut dan ini sangat tergantung pada momen historisnya. Selanjutnya ia menyebutkan beberapa istilah seperti qina', burqu', niqab, litsmah dengan merujuk pada pemakaian penutup muka saja. Sedangkan ketika merujuk pada tutup kepala, kadang-kadang juga digunakan untuk menutupi sebagian muka, maka kata yang digunakan adalah khimar, sitara, 'abayah atau immah. ${ }^{16}$

Secara normatif, setidaknya ada ayat dalam Al Qur'an yang berbicara tentang perintah penggunaan penutup kepala (jilbab), yakni: Q.S. al Ahzâb ayat 59 dan Q.S. an Nûr ayat 31. Pada ayat 59 surah alAhzâb redaksi amarnya ditujukan kepada Nabi secara personel sebagai berikut:

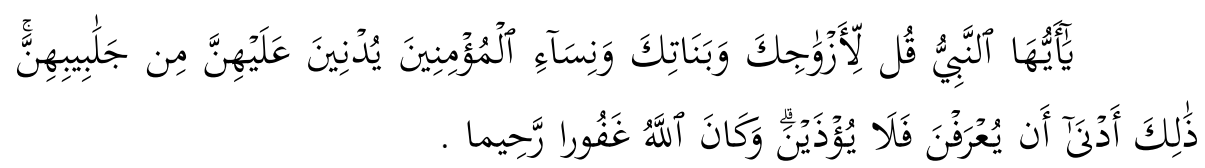

14"Hasil Pencarian - KBBI Daring," accessed October 10, 2018, https://kbbi.kemdikbud.go.id/entri/jilbab.

${ }^{15} \mathrm{Fadwa}$ El Guindi, Jilbab: antara Kesalehan, Kesopanan dan Perlawanan (Penerbit Serambi, 2003), 30-31.

${ }^{16}$ Guindi, 32. 
Hai Nabi, katakanlah kepada isteri-isterimu, anak-anake perempuanmu dan isteri-isteri orang mukmin: "Hendaklah mereka mengulurkan jilbabnya (ke selurub tubub mereka)". Yang demikian itu supaya mereka lebih mudah untuk dikenal, karena itu mereka tidak diganggu. Dan Allah adalah Maha Pengampun lagi Maha Penyayang.

Sementara pada ayat 31 surat an-Nûr, bunyi amarnya lebih luas dan ditujukan kepada seluruh wanita muslimah, yang redaksi lengkapnya sebagai berikut:



Katakanlah kepada wanita yang beriman: "Hendaklab mereka menaban pandangannya, dan kemaluannya, dan janganlah mereka menampakekan perbiasannya, kecuali yang (biasa) tampak dari padanya. Dan hendaklah mereka menutupkan kain kudung ke dadanya, dan janganlah menampakekan perhiasannya kecuali kepada suami mereka, atau ayah mereka, atan ayah suami mereka, atau putera-putera mereka, atan puteraputera suami mereka, atau saudara-saudara laki-laki mereka, atau puteraputera saudara lelaki mereka, atau putera-putera saudara perempuan mereka, atau wanita-wanita muslimah, atau budak-budak yang mereka miliki, atau pelayan-pelayan laki-laki yang tidak mempunyai keinginan (terhadap wanita) atau anak-anak yang belum mengerti tentang aurat wanita. Dan janganlah mereka memukulkan kakinya agar diketabui perbiasan yang mereka sembunyikan. Dan bertaubatlah kamu sekalian kepada Allah, hai orang-orangyang beriman supaya kamu beruntung. 
Para mufassir seperti Imâm ar Râzî dan al Wâhidy meriwayatkan bahwa pada zaman dahulu, para wanita baik yang merdeka maupun yang budak, keluar pada malam hari bila ingin buang air di antara semak dan pohon. Sehingga tidak bisa dibedakan antara wanita merdeka dan budak. Orang-orang fasiq di Madinah sebagaimana kebiasaan jahiliyah sering menggoda para budak wanita. Namun seringkali malah menggoda para wanita merdeka dengan alasan bahwa mereka salah kira. Sehingga turunlah ayat ini untuk membedakan antara wanita merdeka dengan budak, yaitu dengan memakai jilbab yang panjang dan lebar. ${ }^{17}$

Dalam Tafsîr al-Qurthuby disebutkan bahwa turunnya surah di atas merupakan teguran terhadap kebiasaan-kebiasaan yang dilakukan oleh wanita-wanita merdeka Arab ketika mereka keluar rumahnya. Dimana seringkali mereka diganggu oleh para lelaki, disebabkan pakaian yang mereka kenakan tidaklah sopan karena kebanyakan mereka mengira bahwa wanita-wanita tersebut adalah hamba sahaya. Untuk menghindarkan para wanita muslimah dari gangguan tersebut serta menampakkan rasa keterhormatan atas diri muslimah maka ayat tersebut diturunkan. ${ }^{18}$

Pemahaman umum terhadap interpretasi mainstreaming mufassir terkait ayat jilbab bahwa aurat perempuan adalah seluruh tubuhnya kecuali bagian muka dan telapak tangannya. Jika bagian-bagian yang dilarang itu dibiarkan terbuka dapat mengundang kejahatan "seksual" bagi perempuan, dan mereka dapat diganggu oleh para lelaki hidung belang, yang mengira bahwa perempuan-perempuan tersebut adalah para budak sahaya. Jika seorang perempuan keluar rumah dengan mengenakan jilbab, maka hal itu menunjukkan keutamaan dan kehormatan dirinya. ${ }^{19}$

Secara kebahasaan, beberapa istilah yang dipergunakan terkait dengan perintah (amar) pengunaan jilbab, yaitu lafadz (يُدِنِنَ) 'yudnîna' yang menunjukkan arti mengulurkan atau memanjangkan. Sedangkanlah (جَلَنبِيِب) 'jalâbîb' adalah 'malhafab', semacam kain penutup tubuh yang

${ }^{17}$ Lukman Hakim, "Rekonstruksi Figh Hijab Berwawasan Nusantara Kajian Penafsiran Ayat Hukum Dalam Qs. Al-Ahzab: 59," Ar-Risalah: Media Keislaman, Pendidikan Dan Hukum Islam 12, no. 2 (2014): 88-102.

${ }^{18}$ Lihat Al-Qurthubiy, Tafsir ul-Qurtubiy, (Kairo: Dâr al-Sya'b, t.t) Jilid VI, 4621.

${ }^{19} \mathrm{Abu}$ Iqbal Mahalli, Muslimah Modern: dalam Bingkai al-Quran dan al-Hadis (Yogyakarta: LeKPIM, 2000), 172. 
belum dijahit atau sesuatu yang dapat menutupi aurat, baik terbuat dari kain atau bahan lainnya. ${ }^{20}$

Mufassir Ibnu Jarir meriwayatkan bahwa Muhammad Ibnu Sirrin pernah bertanya kepada Abidah al-Salamani tentang maksud penggalan ayat tersebut. Lalu Abidah mengangkat semacam selendang yang dipakainya, kemudian memakaikannya sambil menutup kepalanya, sehingga tertutup pula kedua alis dan wajahnya dan membuka mata kirinya untuk melihat dari arah sebelah kirinya. Kemudian al-Alusi menyatakan bahwa maksud dari kata (عَلَيْهِنَّ) 'alaibinna' adalah seluruh tubuh mereka atau seluruh badan mereka tertutupi oleh pakaian. Namun menurutnya ada juga pendapat yang menyatakan kata tersebut adalah di atas kepala mereka atau wajah mereka, karena pada masa jahiliyyah yang biasa tampak dari seorang perempuan adalah wajahnya. ${ }^{21}$

Al-Biqa'i (1406-1480 M) sebagaimana yang dikutip Quraish Shihab menyebutkan beberapa makna dari kata 'jilbab' tersebut dengan baju yang longgar atau penutup kepala atau pakaian yang menutupi baju dan kerudung yang dipakai perempuan. Selanjutnya kalau yang dimaksud dengan jilbab adalah baju, maka ia merupakan pakaian yang harus menutup tangan dan kakinya. Sementara kalau ia dimaknai dengan kerudung, maka wajib baginya untuk mengulurkannya dengan menutup wajah dan leher. Sedangkan kalau jilbab itu dimaknai dengan pakaian yang menutupi baju, maka perintah mengulurkannya adalah membuatnya longgar sehingga menutup semua badan dan pakaiannya. ${ }^{22}$

Muhammad Thâhir Ibn 'Âsyûr dalam bukunya Maqâshid asySyari’ah, sebagaimana dikutip oleh Quraish Shihab, memahami kata jilbab dengan arti pakaian yang lebih kecil dari jubah tetapi lebih besar dari kerudung atau penutup wajah. Penutup ini diletakkan di atas kepala dan terulur kedua sisinya melalui pipi hingga menutupi seluruh bahu dan belakang. Selanjutnya dijelaskan pula, bahwa bentuk jilbab atau model jilbab tersebut bisa bermacam-macam sesuai dengan 'selera' perempuan, mengikuti adat kebiasaan yang berlaku. Akan tetapi tujuan utama dari

\footnotetext{
${ }^{20}$ Hidayanto, “Aurat Wanita Dalam Aturan Hukum,” 80.

${ }^{21}$ Mahmud al-Alusi, Rûh al-Ma'âni, Cet. Ke-4, Jilid 22 (Kairo: Al-Muniriyah, 1985), 89

${ }^{22}$ M. Quraish Shihab, Jilbab: Pakaian Wanita Muslimah ; Pandangan Ulama Masa Lalu dan Cendekiawan Kontemporer (Jakarta: Lentera Hati, 2009), 88.
} 
ayat ini adalah "menjadikan mereka lebih mudah dikenali, sehingga mereka tidak mudah diganggu." 23

Berbeda dengan mainstreaming para mufassir, Muhammad Syahrûr, seorang pemikir muslim kontemporer, memiliki pandangan yang menarik dalam menjelaskan tentang persoalan jilbab. ${ }^{24}$ Menurutnya hijab (jilbab) sebagai pakaian tertutup bukanlah merupakan penetapan hukum (tasyri), akan tetapi lebih merupakan bentuk pengajaran (ta'lim) untuk menghindari terjadinya gangguan. Hal ini disebabkan antara lain karena khitab dari ayat tersebut ditujukan kepada Muhammad saw dalam kapasitas beliau sebagai seorang nabi, bukan rasul. ${ }^{25}$ Selain itu ayat ini pun turunnya di Madinah dengan metode pemahaman yang bersifat lokal-temporer yang sangat terkait dengan konteks perempuan Madinah agar tidak mengalami pelecehan dari laki-laki usil saat mereka beraktivitas di luar rumah. ${ }^{26}$ Dengan kata lain, jilbab merupakan satu bentuk pakaian yang hadir karena tuntutan kehidupan bermasyarakat, dan senantiasa bisa berubah tergantung pada perubahan dalam masyarakat itu sendiri. Menurutnya pada masa sebelum kedatangan Islam kemudian setelah kenabian Muhammad saw dan sesudahnya, jilbab merupakan jenis pakaian yang berfungsi untuk membedakan jenis pakaian perempuan merdeka dengan hamba sahaya. Pakaian perempuan merdeka, sebagaimana yang dipakai oleh Khadijah ra. adalah penutup kepala yang berfungsi untuk menghalau sengatan terik matahari, menghimpun rambut sehingga tidak berantakan, dan pakaian panjang yang menutup seluruh bagian bawah badan. Pakaian mereka pun longgar, hingga

${ }^{23}$ M. Quraish Shihab, Tafsir Al Misbah, vol. 10 (Jakarta: Lentera Hati, 2010), 534.

${ }^{24}$ Syahrur meniscayakan pembacaan ulang atas Alquran sehingga Islam yang relevan dengan segala ruang dan waktu (shâlih li kulli zamân wa makân) dapat terwujud. Pembacaan baru tersebut diterapkan dalam upaya merekonstruksi rukun Islam dan rukun iman yang sudah baku selama ini. Muhammad Syahrur, Al-Kitâb Wa Al-Qur'ân: Qirâ'ah Mu'âshirah (Damaskus: Al-Ahâly Lithibâ'ah wa al-Nasyr wa al- Tauzî', 1990).; Muhammad Syahrur, Al-Islâm Wa Al-Îmân Manæhhumatul Qiyam (Damaskus: al-Ahâly Lithibâ'ah wa al-Nasyr wa al-Tauzî', 1996).; M. Zainal Abidin, "Reformulasi Islam Dan Iman: Kembali Kepada Tanzil Hakim Dalam Perspektif Muhammad Syahrur," Millah: Jurnal Studi Agama 3, no. 1 (2016): 108-122.

${ }^{25}$ Abdul Mustaqim, "Pemikiran Fikih Kontemporer Muhamad Syahrur Tentang Poligami Dan Jilbab," Al-Manabij: Jurnal Kajian Hukum Islam 5, no. 1 (2011): 75.

${ }^{26}$ Muhammad Alim Khoiri, "Rekonstruksi Konsep Aurat (Analisis Pemikiran Syahrur)," Universum 9, no. 2 (2015): 156. 
memudahkan mereka untuk beraktivitas, di luar maupun di dalam ruangan. Menurutnya lagi bentuk atau model pakaian mereka tidak mempunyai banyak bagian yang terbuka, kecuali satu, bagian atas tempat memasukkan kepala. Hingga apabila mereka menunduk, maka bagian dada akan dengan mudah terlihat_- terlebih kalau belahannya lebar. Oleh karenanya ayat tersebut diturunkan agar memakai penutup kepala yang menjuntai hingga ke bawah, sehingga ketika mereka beraktivitas, bagian dada yang menjadi aurat bagi mereka tidaklah dapat terlihat. ${ }^{27}$

Secara spesifik, berbeda dengan pandangan mainstreaming fuqaha, Syahrur memberikan argumentasi bahwa jilbab itu hanyalah sebuah ta'lim bukan sebuah tasyri' yang mengikat. Pendapatnya ini tampaknya menyesuaikan dengan teori limit (budud) yang dibangunnya. Jilbab berada pada bagian tabsinat, penyempurnaan tampilan seorang perempuan. Jilbab lebih merupakan upaya perwujudan nilai etis kultural. ${ }^{28}$

Dalam konteks Indonesia, penerjemahan Mahmud Yunus dan Hamka terhadap surat al-Nur ayat 31 dan al-Ahzab ayat 59 di atas memperlihatkan sisi menarik lainnya. Kedua tokoh di atas tidak menerjemahkan khimar (خمر) dengan istilah jilbab, dimana istilah ini lah yang lebih populer saat ini. Istilah jalâbib diterjemahkan oleh Mahmud Yunus dengan baju mantel, sementara Hamka tetap menggunakan kata jilbab dengan makna yang berbeda. Hal ini menggambarkan bahwa istilah jilbab sebagaimana populer saat ini, yaitu sebagai padanan dari kata khimar, belumlah populer semasa penulisan terjemahan Mahmud

${ }^{27}$ Adanya perintah ini, menjadikan ciri serta kedudukan sosial dari perempuan merdeka dan hamba sahaya menjadi lebih jelas statusnya. Menurut Syahrur, kejelasan status tersebut_-perempuan merdeka atau hamba sahaya-memberikan implikasi yang berbeda, baik perlakuan maupun tindakan hukum. Hal ini menjadi sangat penting untuk dilakukan karena jumlah hamba sahaya yang semakin bertambah seiring dengan makin luasnya daerah kekuasaan Islam. Lihat juga Shihab, Jilbab, 175-76. Sebagai contoh adalah perlakuan masa iddah bagi wanita hamba sahaya selama satu bulan setengah ketika dicerai, dua bulan lima hari jika ia ditinggal wafat suaminya.

${ }^{28}$ Pandangan Syahrur tentang hukum cukup unik, semangatnya kembali kepada nash (return to the text), tetapi tidak kaku, melainkan sangat fleksibel, karena ada kategori batas atas dan batas bawah, yang menjadikan hukum lebih dinamis. Pandangan lebih lanjut tentang teori ini, lihat M. Zainal Abidin, "Gagasan Teori Batas Muhammad Syahrûr Dan Signifikansinya Bagi Pengayaan Ilmu Ushul Fiqh," Al-Mawarid Journal of Islamic Law 15 (2006). 
Yunus-Ia memulai menerjemahkan Alquran pada tahun 1922 dan diterbitkan pertama kali pada tahun $1935 .{ }^{29}$

Selanjutnya, Hamka menerjemahkan khimar sebagai selendang, dan mudawarah sebagaimana yang digunakan oleh Rahmah el-Yunusiah ia juga sebut sebagai selendang. Pada sisi lain, jilbab bagi Hamka adalah pakaian yang menutup seluruh tubuh, kecuali tangan dan muka; pandangan yang sejajar dengan istilah baju mantel versi Mahmud Yunus. Dalam konteks ini, bagi Hamka, jilbab dibawa masuk ke Indonesia melalui perjalanan haji. Perempuan-perempuan yang pulang haji akan menggunakan jilbab ketika ia sampai di kampung halamannya. Hanya saja, kita belum mendapatkan informasi bagaimana jilbab dalam makna Alquran, sebagai baju mantel, ketika sampai di Indonesia menjadi pakaian penutup kepala, leher, dan dada, bentuk yang sepadan dengan istilah khimar. ${ }^{30}$

Pada zaman Orde Lama dan fase awal Orde Baru, sebelum era bergulirnya isu kebangkitan Islam di penghujung tahun 1970-an, kata jilbab belumlah dikenal, dan jikalau istilah itu sudah populer, tentu saja Mahmud Yunus dan Hamka akan menggunakannya dalam terjemahan mereka. Konsep jilbab oleh karenanya banyak dipengaruhi oleh faktor eksternal, yang dalam hal ini munculnya ghirah kembali kepada Islam, yang merupakan bagian dari semangat kebangkitan Islam (an Nahdhah al Islamiyyah/ Islamic resurgence).

\section{Kontektualisasi Jilbab: Mendialogkan Teks dengan Konteks}

Meminjam istilah Geertz, tradisi berjilbab adalah sebuah fenomena yang kaya makna dan penuh nuansa. ${ }^{31}$ Fadwa El Guindi juga menyatakan bahwa jilbab merupakan fenomena yang kaya dan penuh makna. Baginya jilbab berfungsi sebagai bahasa yang bertugas untuk menyampaikan pesan sosial dan budaya. Bagi orang Kristen khususnya Katolik, jilbab merupakan pandangan keperempuanan dan kesalehan. ${ }^{32}$

\footnotetext{
${ }^{29}$ Fadli Lukman, "Sejarah Sosial Pakaian Menutup Kepala Muslimah Di Sumatera Barat," Musāwa 13, no. 1 (2014): 53. Barat."

${ }^{30}$ Lukman, "Sejarah Sosial Pakaian Menutup Kepala Muslimah Di Sumatera

${ }^{31}$ Clifford Geertz, Kebudayaan dan agama (Jakarta: Kanisius, 1992).

${ }^{32}$ Guindi, Jilbab, 16.
} 
Secara historis, pemakaian jilbab sudah dimulai atau bisa ditelusuri dari kehidupan bangsa Mesopotamia/Persia dan kaum Hellenis/Byzantium Romawi. ${ }^{33}$

Secara khusus, sebagaimana dilaporkan Ahmed tentang asal muasal pemakaian jilbab ini, dengan mengadakan penelitian terhadap benda-benda historis kuno dan modern, bahwa Islam tidak memperkenalkan jilbab. Tidak berbeda dengan hasil penelitian yang dilakukan oleh Hansen pada tahun 1939, yang dengan penuh empati mengatakan bahwa Nabi Muhammad tidak memperkenalkan kebiasaan dalam berjilbab. Ahmed juga menjelaskan bahwa sebelum Islam datang, penggunaan jilbab hanyalah merupakan bagian dari adat yang kadangkadang dipakai dan kadang-kadang tidak. Menjadi terinstitusionalisasi semenjak Islam mengadopsinya sebagai bagian dari ajaran yang mengajak perempuan merdeka untuk lebih terjaga kehormatannya. ${ }^{34}$ Selanjutnya memakai jilbab telah menjadi sebuah keyakinan dan pegangan hidup yang dianggap merupakan bagian dari tradisi yang luar biasa dari ajaran Islam dan bagi umat Islam. Berjilbab pada akhirnya merupakan sebuah tuntunan agama, simbol identitas, cara berkomunikasi serta bisa menjadi alat perlawanan. ${ }^{35}$

Dibeberapa tempat, penggunaan jilbab sebagai penutup kepala dan badan sering tidak memperhatikan pada aspek gender. Misalnya 'abayah sejenis mantel dengan penutup kepala yang bisa digunakan oleh laki-laki dan juga perempuan. Kemudian burqu' atau niqab bahkan sering digunakan laki-laki di masyarakat Badui sebagai simbol kejantanan. Sedangkan motif dan warna jilbab pun memiliki makna tertentu bagi perempuan Badui di Kawasan Timur Tengah. Misalnya seorang perempuan ketika sudah menikah, ia akan menggunakan jilbab berwarna hitam dengan ikat pinggang warna merah. Warna hitam menyampaikan pesan bahwa tidak ada manusia yang luput dari kesalahan dan dosa.

${ }^{33}$ Ahmad Suhendra, "Kontestasi Identitas Melalui Pergeseran Interpretasi Hijab Dan Abstrak Jilbab Dalam Al Qur'an," PALASTREN Jurnal Studi Gender 6, no. 1 (2016): 6 .

${ }^{34}$ Guindi, 38.

${ }^{35}$ Guindi, 8. 
Sedangkan warna merah merupakan simbol penciptaan yang diasosiasikan kepada darah menstruasi. ${ }^{36}$

Akhirnya dapat dikatakan bahwa jilbab adalah merupakan produk budaya, sekaligus tuntutan agama. Sebagai produk budaya, ternyata memakai jilbab itu sudah mulai ada sebelum Islam itu datang. Bahkan menurut beberapa ahli tafsir, masyarakat Jahiliyah masa itu sebenarnya tidaklah asing dengan jilbab. Bahkan mereka ketika berhadapan dengan laki-laki yang bukan mahramnya atau berada di luar rumah selalu memakai apa yang disebut dengan jilbab. Seorang perempuan ketika menginjak dewasa diajarkan untuk memakai jilbab untuk menyimbolkan kemuliaan dan perbedaan mereka dengan hamba sahaya, sehingga bangsa Arab masa itu mewajibkan pada putri mereka untuk mengenakan jilbab dan mereka menganggap ini sebagai sebuah tradisi yang harus dilaksanakan. ${ }^{37}$

Hanya saja dalam perkembangannya kemudian, terutama pada periode awal Islam di Madinah, perempuan muslimah sering mengenakan baju dan penutup kepala sama dengan yang dikenakan oleh perempuan-perempuan Arab pada umumnya dengan menggunakan pakaian dan penutup kepala yang terbuka hingga memperlihatkan bentuk telinga, leher dan dada mereka. Kondisi semacam ini kemudian mengundang para lelaki munafik senang menggoda mereka, termasuk juga para perempuan muslim. Laki-laki ini mengira bahwa perempuanperempuan tersebut adalah hamba sahaya. Hal inilah yang kemudian ingin diperbaiki oleh Islam dengan diturunkannya surah Al Alhzâb: 59 dan An-Nûr: 31.

Saat ini berjilbab bukanlah merupakan hal yang aneh lagi di Indonesia. Padahal kalau melihat pada era 70-80an, memakai jilbab adalah sesuatu yang aneh, kuno, kampungan dan memalukan. Skeringkali seringkali mahasiswa yang sekolah di IAIN atau siswa PGAN saat itu enggan memakai jilbab dari rumah karena seringnya mereka diolok-olok. Mereka baru mengenakan jilbab saat akan memasuki halaman kampus atau sekolah. ${ }^{38}$

${ }^{36}$ Budiati, "Jilbab," 61.

${ }^{37}$ Shihab, Jilbab, 85-87.

${ }^{38}$ Hatim Badu Pakuna, "Fenomena Komunitas Berjilbab; Antara Ketaatan Dan Fashion," Farabi 11, no. 1 (2014): 4. 
Menurut Guindi, respon tersebut sangatlah meremehkan, dengan bahasa eksklusif dan materialis; mereka yang menutup kepalanya disebabkan karena tidak punya uang untuk pergi ke salon menata rambutnya, atau mereka berjilbab karena menutupi kekurangan yang ada pada diri mereka. Sampai pada pemeringkatan strata sosial dengan mengatakan bahwa orang berjilbab adalah golongan masyarakat miskin, terbelakang. Lebih ekstrim lagi ketika dikatakan bahwa mereka yang memakai jilbab dan baju longgar sebenarnya ingin menutupi aib karena hubungan seksual di luar nikah. ${ }^{39}$ Begitu jeleknya label yang disematkan kepada para perempuan berjilbab masa itu. Tapi yang terjadi saat ini justru sebaliknya. Perempuan berjilbab demikian mudah ditemui, dan justeru sesuatu yang "aneh" kalau masa sekarang seorang perempuan tidak menggunakan jilbab. Jilbab sudah menjadi tren dan sudah menjadi sebuah fashion bagi perempuan Indonesia saat ini, bukan hanya sebagai panggilan keberagamaan seseorang.

Lahirnya tren berjilbab di Indonesia tidak bisa dilepaskan dari peran para artis, seniman dan elite santri di era 80-an. Sebagaimana telah disebutkan didalam pendahuluan, peran dari lagu BIMBO cukup besar bagi terbentuknya semangat perempuan Indonesia untuk berjilbab. Adanya grup Nada Ria atau Nasida Ria, yang membawakan lagu dengan judul Jilbab Putih, juga ikut memberikan semangat yang kuat bagaimana seharusnya penampilan seorang muslimah. Bagaimana kemudian lagu ini mampu memberikan image positif bagi perempuan berjilbab yang pada akhirnya diidentikkan dengan kesalehahan dan ketakwaan, seperti yang diungkapkan salah satu nitizen dalam tayangan video di youtube pada lagu tersebut, "kalau dulu melihat perempuan pakai jilbab sudah pasti dia salehah". ${ }^{40}$

Aminuddin menyebutkan bahwa elite santri sangat berperan terhadap sikap pemerintah Orde Baru-yang pada masa awal sekitar tahun 70an sampai awal 80-an begitu Islamo phobia. Banyaknya elite santri yang berkiprah di dalam pemerintahan pada akhirnya menjadikan sikap

\footnotetext{
${ }^{39}$ Guindi, Jilbab, 265-66.

40"Nida Ria - Jilbab Putih [Official Music Video] - YouTube," accessed October 11 , 2018 , https://www.youtube.com/watch?v=MZHoIZif_K8\&start_radio=1\&list=RDMZHoI Zif_K8.
} 
pemerintah lebih akomodatif terhadap umat Islam. Salah satu bentuk akomodatif yang bersifat struktural adalah keluarnya izin kebolehan bagi pelajar dan mahasiswa untuk memakai jilbab saat mereka di sekolah maupun kampus pada tahun 1991. ${ }^{41}$ Dari sini, akhirnya pemakaian jilbab semakin pesat, dan menjadi sesuatu yang sudah lumrah dan tidak lagi digugat keberadaannya.

Bahkan, keberadaan jilbab semakin menunjukkan perkembangan yang berbeda, bahwa ia tidak lagi berfungsi sebagai penutup aurat, tetapi juga sebagai bagian dari trend berbusana masa kini. Adanya era globalisasi yang ditandai dengan kemajuan teknologi dan informasi telah membawa banyak perubahan bagi gaya hidup masyarakat dalam berbusana (fashion). Berpenampilan cantik, trendi, tidak ketinggalan zaman merupakan gejala sosial yang ditimbulkan. Disematkannya image tersebut tentu banyak membawa perubahan bagi gaya berjilbab perempuan saat ini. Dari sini akhirnya lahirlah perkumpulanperkumpulan perempuan berjilbab yang dikenal dengan komunitas hijaber (bijabers community), terdiri dari remaja dan ibu-ibu yang berpenampilan cantik, dengan dandanan yang soft, berbusana dengan model yang stylish, berbeda dengan busana muslim kebanyakan.

Menurut Pakuna, komunitas ini dibangun untuk memberikan motivasi, contoh bagi kalangan yang masih ragu-ragu untuk memakai jilbab. Tampilnya desainer muda Dian Pelangi yang menampilkan rancangan busana muslim modern dengan mengadopsi beragam bentuk pakaian dan jilbab dari berbagai daerah di belahan dunia, pada akhirnya mampu menarik para remaja dan ibu-ibu untuk mengenakan jilbab, mengikis anggapan kuno dan kampungan bagi pemakainya. Untuk lebih memperkenalkan tren jilbab, komunitas ini pun sering mengadakan event Hijab Class, memberikan tutorial teknik memakai jilbab yang modis, trendi namun tetap menutup aurat. Juga memperkenalkan produkproduk terbaru mereka ke berbagai jejaring sosial online. ${ }^{42}$

Selanjutnya, masih berkaitan dengan fenomena jilbab, adapula komunitas yang memperkenalkan mereka dengan istilah komunitas jilboobs. Komunitas ini lahir pada bulan Agustus 2014 disebuah akun

\footnotetext{
${ }^{41}$ Aminudin, Kekuatan Islam dan pergulatan kekuasaan di Indonesia: sebelum dan sesudah runtuhnya rezim Soeharto (Yogyakarta: Pustaka Pelajar, 1999), 229, http://books.google.com/books?id=8PTjAAAAMAAJ.

42 Pakuna, "Fenomena Komunitas Berjilbab; Antara Ketaatan Dan Fashion."
} 
medsos facebook. Berpenampilan jilbab apa adanya namun masih tetap memperlihatkan lekuk-lekuk tubuh. Mereka biasanya suka memakai celana ketat, berbahan kaos atau levis (legging), memakai kaos ketat lengan panjang dan atau ditutupi dengan kain transparan. Biasanya komunitas ini berasal dari para perempuan muslim yang senang memakai pakaian ketat, namun karena tuntutan lingkungan bahwa perempuan muslim harus menutup aurat, pada akhirnya membuat mereka harus beradaptasi dengan hal ini. ${ }^{43}$

Anti thesis dari kelompok di atas adalah mereka yang menampilkan pemakaian jilbab lebar yang kerap dipanggil dengan istilah jilbaber. Kebanyakan mereka menggunakan gamis, baju kurung dengan rok, yang kesemuanya terlihat longgar dan lebar. Jilbab yang mereka gunakan pun panjang dan lebar hampir menutupi pakaian yang mereka gunakan. Pada awalnya memang tampilan, corak warna dari pada jilbab mereka cenderung monoton, hanya berani pada warna-warna gelap saja, seperti hitam, biru malam, cokelat tua. Namun seiring perkembangan, bentuk dan model jilbab mereka pun lebih bervariasi dan lebih berwarna. Itu semua dilakukan agar terhidar dari kesan eksklusif, namun tetap berada pada jalur syar'i. ${ }^{44}$

Fase lain dari jilbab ini juga adalah maraknya penggunaan burqa (jilbab plus penutup muka) sebagai bagian dari simbol kesalehan. Apabila dahulu, cukup dengan penggunaan jilbab yang rapih sebagaimana figur Aisyah dalam kidung Bimbo Aisyah Adinda Kita, sudah menunjukkan indikator kesalehan seorang wanita, maka 'menjamurnya' perempuan berjilbab, menjadikan hal itu tidak cukup lagi, sehingga penggunaan cadar, sebagian bagian dari asesoris jilbaber, menjadi sesuatu yang dengan mudah ditemukan pada masyakat muslimah dewasa ini, tidak ketinggalan juga di kampus-kampus yang berlabelkan Islam.

\section{Analisis Historis Kritis: Dari Teks kepada Konteks}

Bangkitnya semangat Islam pada abad ke-15, telah mendorong para pemikir Islam kontemporer untuk lebih giat melakukan berbagai

43 Pakuna, 8-9.

${ }^{44}$ Ahmadi and Yohana, "Konstruksi Jilbab Sebagai Simbol Keislaman,” 242. 
kajian terhadap tradisi (turats). Setidaknya terdapat tiga kelompok pemikir yang berhadapan dengan kajiannya terhadap turats, yakni kelompok: pertama, mereka mengkaji tradisi berangkat dari teks-teks dalam kapasitasnya sebagai sebuah sistem dan sejauh mana melihat perubahanperubahan yang terjadi pada sisi konsistensi dan inkonsistensi sebuah teks dalam mengungkapkan sebuah pemikiran. Kedua, mereka mengkaji tradisi melalui metode yang langsung diambil dari barat, bacaan yang meniscayakan untuk melakukan dekonstruksi terhadap dogma-dogma eksklusif dan tafsir ortodoks. Ketiga, kelompok yang melakukan kajian dengan metode analisis sejarah, artinya mereka menguji kelompok tekstualis (kelompok pertama) dengan mengaitkannya dengan latar belakang sejarah dan ruang lingkup budaya dan politik, sehingga dengan cara tersebut dapat mendorong untuk mengetahui apa saja yang mungkin diungkapkan dari sebuah teks, apa saja yang tidak diungkapkan dan apa saja yang dikatakan namun didiamkan. ${ }^{45}$

Fenomena jilbab sebagai teks dan konteks tekah menjadi bagian penting dari wacana kebangkitan Islam. Padanya, terdapat dialog antara tradisi (turats) dan modernitas (hadatsab). Sebagaimana yang ungkapkan oleh Geertz dan Guindi, bahwa jilbab adalah sebuah fenomena di masyarakat yang kaya makna dan penuh nuansa. Dialektika antara teks dengan konteks, tarik ulur antara keduanya selalu terjadi di tengah-tengah masyarakat yang dinamis. Perkembangan jilbab di Indonesia sekitar tahun 80 -an terlihat sangat berbeda dengan masa sekarang, lebih dinamis dan bervariasi.

Di era sebelum tahun 80 -an disaat jilbab itu merupakan pakaian yang dianggap aneh dan kuno, para perempuan muslim dengan begitu bersemangat ingin menampilkan citra sebagai perempuan muslim sejati. Meskipun pada masa itu penggunaan istilah yang dirasa lebih tepat adalah kerudung-karena ia hanya menempel di atas kepala, sementara bagian dada masih terlihat. Hal yang sangat ingin ditampilkan saat itu adalah kepada upaya menampilkan kepribadian sebagai seorang muslimah. Selanjutnya seiring dengan semangat kebangkitan Islam pasca Revolusi Iran dan peran sikap akomodatif pemerintah, tampilan kerudung pun mulai berubah, lebih tertutup, yang selanjutnya biasa disebut dengan jilbab. Pada akhirnya jilbab kemudian memberikan kesan yang sangat luar

45Zainal Abidin, Retbinking Islam Dan Iman (Banjarmasin: IAIN ANTASARI PRESS, 2014), 5-7. 
biasa terhadap anggapan bahwa ciri perempuan salehah itu cukup dengan dilihat apakah ia memakai jilbab atau tidak.

Evolusi jilbab ini pun, pada akhirnya tidak terlepas dari perkembangan dan dinamika pemikiran ahli tafsir dan cendikiawan muslim. Sebagaimana Ibnu Jarir dan Al Biqa’i, ketika memberikan tafsir terhadap Q.S. Al Ahzab: 59 bersepakat bahwa mengulurkan jilbab hingga menutupi bagian dada adalah kewajiban yang harus dilakukan seorang perempuan merdeka. Sehingga dengan demikian mereka bisa terhindar dari godaan lelaki hidung belang yang seringkali mengira mereka itu adalah perempuan hamba sahaya. Selain itu kewajiban tersebut juga berfungsi untuk menegaskan status sosial mereka. Ada perbedaan perlakuan bagi perempuan merdeka dan hamba sahaya. Adanya penafsiran yang cenderung kembali kepada 'zahir' teks ayat sangat mungkin dilakukan dimasa itu mengingat kondisi sosial dan politik umat Islam. Kejelasan status dan penghormatan bagi perempuan merdeka saat itu sangat diperlukan untuk menunjukkan kemuliaan ajaran Islam, yang berbeda dan penuh penghormatan terhadap wanita, terlebih pada daerahdaerah yang baru ditaklukkan. Kehadiran komunitas jilbaber, seakan memperkuat pernyataan ini. Dalam beberapa penelitian yang dilakukan mengenai alasan dan motivasi yang melatarbelakangi mereka untuk memakai jilbab lebar adalah ingin melaksanakan ajaran Islam sesungguhnya. Bahwa berjilbab itu seperti yang dicontohkan isteri Rasulullah, Khadijah ra, harus menutupi bagian dada, tidak memperlihatkan bentuk tubuh, tidak menyolok merupakan upaya untuk mewujudkan itu semua. Bahwa hal ini kemudian mengalami pergeseran, itu lebih kepada upaya menghindari kesan eksklusif dan kesan konservatif yang dilontarkan oleh kelompok yang "tidak suka" terhadap komunitas ini.

Sedangkan Muhammad Thâhir Ibn 'Âsyûr (w. 1973), seorang ulama asal Tunisia lulusan Universitas Ez-Zetouna, memahami bahwa Islam memang mensyariatkan bagi perempuan untuk memakai jilbab. Jilbab diperlukan seorang perempuan muslim dalam rangka memelihara kehormatan dirinya-agar tidak diganggu dan agar mudah untuk dikenali. Bahwa jilbab itu kemudian berbaur dengan budaya, tidak kaku dan tidak menafikan aspek historisitas, merupakan sebuah upaya untuk mewujudkan maqâshid syarîah yang menjunjung tinggi pada prinsip al- 
fithrah, al-musâwah, al-samâhah dan al-hurriyah. Pada akhirnya jilbab bisa berkembang sesuai dengan kondisi dimana dia diperlukan, style dan modelnya menyesuaikan dengan kebutuhan perempuan setempat. Bagi Ibn 'Âsyûr tujuan paling penting dari syariat Islam itu adalah terpeliharanya sistem atau tata nilai kehidupan umat dan kelestarian kemaslahatan itu dengan cara menjaga kemaslahatan itu sendiri yang meliputi maslahah akal, perbuatan dan alam dimana ia hidup. Tampilnya komunitas hijabers mewakili akan pendapat ini, menampilkan kepribadian muslimah yang salehah sekaligus berupaya untuk menepis anggapan bahwa jilbab itu merupakan pakaian konservatif dan kuno. Jilbab mereka lebih berwarna, lebih bermotif, dan seringkali motif dan corak tersebut berasal dari daerah tertentu. Lebih menonjolkan kepribadian yang inklusif, lebih terbuka dengan perkembangan zaman. Karenanya seringkali komunitas ini memperkenalkan style hijab mereka dalam akun-akun media sosial.

Berbeda dengan dua kelompok di atas yang tetap menjadikan jilbab itu sebagai bagian tuntutan syariah yang harus dianut umatnya, Syahrur meyakini bahwa maksud Tuhan terhadap ayat 59 surah al-Ahzab dan ayat 31 surah an-Nur itu hanyalah sebuah ta'lim (pengajaran) bahwa pakaian perempuan merdeka itu adalah sebagaimana yang disampaikan dalam ayat tersebut. Bentuk jilbab yang lebar sampai menjuntai menutupi bagian dada perempuan merupakan keharusan pada masa itu dikarenakan model pakaian perempuan kala itu sangat sederhana, berbentuk longdress panjang dengan lubang paling besar terletak pada bagian atas yang berfungsi untuk memasukkan kepala. Berbeda dengan masa sekarang, dimana kaum perempuan memiliki banyak sekali model berpakaian untuk menutupi bagian dada mereka, sebut saja misalnya rompi. Jika maksud daripada ayat itu adalah untuk menghindari terlihatnya bagian dada perempuan, maka bagi Syahrur, untuk saat ini, jilbab itu tidak terlalu dibutuhkan. Pendapatnya ini tampaknya menyesuaikan dengan teori budud yang dibangunnya, bahwa pemakaian jilbab bukan termasuk kewajiban syariah. Jilbab berada pada bagian tabsinat, penyempurnaan tampilan seorang perempuan. Jilbab lebih merupakan upaya perwujudan nilai etis kultural, yang pada akhirnya berimplikasi pada tidak perlunya menuduh perempuan yang tidak memakai jilbab sebagai perempuan yang tidak Islami, sebab selama ia masih menutupi aurat besarnya, al-juyub dengan batas minimal, maka ia masih berada dalam batas budûdullah. Pendapat ini cukup relevan disampaikan Syahrur ketika ia berhadapan 
dengan kondisi masyarakat yang lebih heterogen, juga dengan latarbelakang pendidikannya sebagai seorang insinyur, master dalam bidang mekanika tanah dan geologi, namun memiliki ketertarikan yang sangat tinggi terhadap kajian keislaman. Hal ini dilakukannya karena ia merasa selama ini belum menemukan teori yang dapat memecahkan beragam persoalan umat. Dirinya merasa masih berada pada kungkungan literaur keislaman yang cenderung ideologis baik dalam hal pemikiran kalam maupun fikih. Karenanya tidak mengherankan jika kemudian pemikiran fikih cenderung stagnan, tidak bergerak sama sekali dan sudah final. Sementara persoalan umat terus bermunculan, menghendaki pada penyelesaian solusi.

\section{Simpulan}

Dari uraian di atas dapat diperoleh simpulan bahwa momentum kebangkitan Islam pada abad ke-15 banyak berimplikasi terhadap ghirah umat Islam untuk lebih mengenal, menghayati dan mengamalkan ajaran agamanya, jilbab salah satunya. Ibnu Jarir dan Al Biqa'i, dan Ibnu 'Âsyur ketika memberikan tafsir terhadap QS. Al Ahzab: 59 bersepakat bahwa mengulurkan jilbab hingga menutupi bagian dada adalah kewajiban yang harus dilakukan seorang perempuan merdeka. Sehingga dengan demikian mereka bisa terhindar dari godaan lelaki hidung belang yang seringkali mengira mereka itu adalah perempuan hamba sahaya. Ibnu 'Âsyur kemudian menambahkan bahwa style daripada jilbab itu sendiri bisa berbaur dengan budaya, tidak kaku dan memberikan kenyamanan dari perempuan itu sendiri. Jilbab merupakan sebuah upaya untuk mewujudkan maqâshid syarîah yang menjunjung tinggi pada prinsip alfithrah, al-musâwah, al-samâhah dan al-hurriyah. Sementara bagi Syahrur, jilbab itu hanyalah sebuah ta'lim bukan sebuah tasyri', tidak terlalu dibutuhkan. Pendapatnya ini tampaknya menyesuaikan dengan teori budud yang dibangunnya. Jilbab berada pada bagian tabsinat, penyempurnaan tampilan seorang perempuan. Jilbab lebih merupakan upaya perwujudan nilai etis kultural.

Dengan beragam pemikiran serta dinamika yang dilaluinya, pada akhirnya jilbab bukan lagi hanya merupakan sebuah simbol identitas, tetapi lebih dari itu. Tampilnya beragam komunitas jilbab tersebut telah membentuk sebuah gerakan sosial baru yang membawa nilai modern 
dalam gaya hidup serta membuka peluang bagi berkembangnya sektor baru dalam perekonomian. Pada jilbab telah terjadi 'pertautan' antara tradisi dan modernitas, tuntutan untuk melaksanakan perintah tuhan dan pada saat yang bersamaan disambut dengan riuhnya bisnis jilbab yang memberikan banyak pilihan bagi perempuan muslim untuk tampil menjadi wanita salehah, dan pada saat yang bersamaan tidak kehilangan hasratnya untuk tampil cantik dan mempesona dengan jilbab yang trendi sesuai perkembangan zaman. Wallâhu a'lam.

\section{Daftar Pustaka}

Abidin, M. Zainal. "Gagasan Teori Batas Muhammad Syahrûr Dan Signifikansinya Bagi Pengayaan Ilmu Ushul Fiqh." Al-Mawarid Journal of Islamic Law 15 (2006).

- - . "Reformulasi Islam Dan Iman: Kembali Kepada Tanzil Hakim Dalam Perspektif Muhammad Syahrur." Millah: Jurnal Studi Agama 3, no. 1 (2016): 108-122.

- - . "Revolusi Iran \& Kebangkitan Kembali Dunia Islam." In Tafsir Filsafat Atas Kehidupan: Risalah Seputar Filsafat Dan Isu-Isu Aktual Keislaman. Yogyakarta: PP UII Press, 2007.

Abidin, Zainal. Rethinking Islam Dan Iman. Banjarmasin: IAIN ANTASARI PRESS, 2014.

Abu-Rabi', Ibrahim M. Intellectual Origins of Islamic Resurgence in the Modern Arab World. New York: SUNY Press, 1996.

Ahmadi, Dadi, and Nova Yohana. "Konstruksi Jilbab Sebagai Simbol Keislaman." MediaTor (Jurnal Komunikasi) 8, no. 2 (2007): 235-248.

"Aisyah Adinda Kita Lirik - YouTube." Accessed October 13, 2018. https://www.youtube.com/results?search_query=aisyah+adin da+kita+lirik.

Alatas, Alwi, and Fifrida Desliyanti. Revolusi Jilbab: Kasus Pelarangan Jilbab Di SMA Negeri Se-Jabotabek, 1982-1991. Jakarta: AlI'tishom Cahaya Umat, 2001.

Aminudin. Kekuatan Islam dan pergulatan kekuasaan di Indonesia: sebelum dan sesudah runtuhnya rezim Soeharto. Yogyakarta: 
Pustaka Pelajar, 1999.

http://books.google.com/books?id=8PTjAAAAMAAJ.

Bakhash, Shaul. The Reign of the Ayatollahs: Iran and the Islamic Revolution. Basic Books, 1984.

Budiati, Atik Catur. "Jilbab: Gaya Hidup Baru Kaum Hawa." Jurnal Sosiologi Islam 1, no. 1 (2011).

Esposito, John L, and Bakri Siregar. Dinamika kebangunan Islam:

watak, proses dan tantangan. Jakarta: Rajawali, 1987.

Geertz, Clifford. Kebudayaan dan agama. Jakarta: Kanisius, 1992.

Guindi, Fadwa El. Jilbab: antara kesalehan, kesopanan dan

perlawanan. Penerbit Serambi, 2003.

Hakim, Lukman. "REKONTRUKSI FIQH HIJAB BERWAWASAN

NUSANTARA Kajian Penafsiran Ayat Hukum Dalam Qs. Al-

Ahzab: 59." Ar-Risalah: Media Keislaman, Pendidikan Dan

Hukum Islam 12, no. 2 (2014): 88-102.

"Hasil Pencarian - KBBI Daring." Accessed October 10, 2018.

https://kbbi.kemdikbud.go.id/entri/jilbab.

Hidayanto, M. Fajar. "Aurat Wanita Dalam Aturan Hukum." Al-

Mawarid 5 (2016): 75-85.

Khoiri, Muhammad Alim. "Rekonstruksi Konsep Aurat (Analisis

Pemikiran Syahrur)." Universum 9, no. 2 (2015).

Lukman, Fadli. "Sejarah Sosial Pakaian Menutup Kepala Muslimah Di

Sumatera Barat." Musāwa 13, no. 1 (2014): 47-57.

Mahalli, Abu Iqbal. Muslimah Modern: dalam Bingkai al-Quran dan al-Hadis. Yogyakarta: LeKPIM, 2000.

Mustaqim, Abdul. "Pemikiran Fikih Kontemporer Muhamad Syahrur

Tentang Poligami Dan Jilbab." Al-Manahij: Jurnal Kajian

Hukum Islam 5, no. 1 (2011): 67-80.

Muzaffar, Chandra. "Kebangkitan Islam: Suatu Pandangan Global

Dengan Ilustrasi Dari Asia Tenggara." In Pembangunan Dan

Kebangkitan Islam Di Asia Tenggara, edited by Saiful Muzani. Jakarta: LP3ES, 1993.

Najib, Ainun. "Pementasan Drama Lautan Jilbab Karya Emha Ainun Nadjib Dalam Fenomena Pelarangan Menggunakan Jilbab Bagi 
Pelajar Muslimah Di Sekolah-Sekolah Negeri Di Indonesia (1986-1989 M)." PhD Thesis, UIN Sunan Ampel Surabaya, 2017.

"Nida Ria - Jilbab Putih [Official Music Video] - YouTube." Accessed October 11, 2018.

https://www.youtube.com/watch?v=MZHolZif_K8\&start_radi $\mathrm{o}=1 \&$ list=RDMZHolZif_K8.

Pakuna, Hatim Badu. "Fenomena Komunitas Berjilbab; Antara Ketaatan Dan Fashion." Farabi 11, no. 1 (2014): 124.

Shihab, M. Quraish. Jilbab: pakaian wanita Muslimah ; pandangan ulama masa lalu dan cendekiawan kontemporer. Jakarta: Lentera Hati, 2009.

- - . Tafsir Al Misbah. Vol. 10. Jakarta: Lentera Hati, 2010. Suhendra, Ahmad. "Kontestasi Identitas Melalui Pergeseran Interpretasi Hijab Dan Abstrak Jilbab Dalam Al Qur'an." PALASTREN Jurnal Studi Gender 6, no. 1 (2016): 1-22.

Syahrur, Muhammad. Al-Islâm Wa Al-Îmân Manzhûmatul Qiyam. Damaskus: al-Ahâly Lithibâ'ah wa al-Nasyr wa al-Tauzî', 1996.

- - . Al-Kitâb Wa Al-Qur'ân: Qirâ'ah Mu'âshirah. Damaskus: AlAhâly Lithibâ'ah wa al-Nasyr wa al- Tauzî', 1990.

Wahyudi Nasution. "Lautan Jilbab, Episode Awal Menuju Maiyah." MEPNEWS.ID, November 21, 2016. https://mepnews.id/2016/11/21/lautan-jilbab-episode-awalmenuju-maiyah/. 